\title{
A Spatial Framework for the Distribution of Public Primary Schools in Munya Local Government Area of Niger State, Nigeria
}

\author{
${ }^{1}$ Shaibu, S.I., ${ }^{2}$ Morenikeji, O.O., ${ }^{1}$ Idowu, O.O., ${ }^{1}$ Medayese, S., ${ }^{1}$ Ohadugha, C.B., ${ }^{2}$ Oliver, M. S ${ }^{2}$ and \\ ${ }^{3}$ Jimoh, M. Y. \\ ${ }^{1}$ Department of Urban and Regional Planning, Federal University of Technology, Minna \\ ${ }^{2}$ Urban and Regional Planning Department, Zungeru Polytechnic, Niger State \\ ${ }^{3}$ Urban and Regional Planning Department, University of Ilorin, Ilorin, Nigeria \\ *Corresponding Author's: eemayusuf@gmail.com, Tel: +2348065273880
}

\begin{abstract}
Education is the key to development in any society and it is true that the educational institutions in any given society reflect the standard of living and the attitudes towards life of that society. This study presents a spatial framework of public primary schools in Munya Local Government Area of Niger state with the specific objectives of identifying the various public primary schools in the study area, attempt a spatial mapping and distribution pattern of the schools; determine spatial equity and accessibility of pupils to the schools and finally to advance appropriate planning policy measures to resolve the identified problems. The main sources of data for the study are through the primary and secondary sources. The location quotient, distributional equity, Gini co - efficient and $P$ - median techniques were used for data analysis. It is observed that primary school's provision has surpassed the maximum required in the area. It is therefore recommended that there should be be guided in the sitting of future schools, while maintenance of the existing ones should be pursued to sustain the likely future growth in school's enrolment. Furthermore, the establishment of future public schools should be based on threshold population in the study area.
\end{abstract}

Keywords: Infrastructural Investment, Community Facilities, Spatial Equity and Spatial Distribution

\section{Introduction}

Investment in community facilities is capital intensive; it requires huge capital outlay and the returns in the form of revenues are often not immediate in the short run. As a result, such facilities are normally provided by the government, indeed the social nature of the facilities implies that it should be the responsibility of the government to ensure every member of the society irrespective of social and economic status or place of residence has access to such facilities (Allen Consulting Group, 2003, Frischmann, 2007). Thus, central to the issue of provision of social facilities is that of the location and spatial distribution of such facilities. The effectiveness of any community facility, among which is education, depends on the location characteristics, as it affects the level of accessibility by the population being catered for. Education is basic to human welfare and is a fundamental necessity for any community; therefore, the education of a people has a direct correlation with the productive capacity and labour efficiency of that community (Olaniyan, and Okemakinde, 2008).

One of the main objectives for economic development planning in a country like Nigeria is to maximize the welfare of the people living in its various parts and therefore public services must be located in such a way that the total cost or effort of the people moving to the facilities is minimized 
(Mabogunje,1974). Efficient schools' locations will save children's time and also encourage parents to send their children to school.

Education, as clearly declared in the National Policy on Education, has been adopted as an instrument "par excellence" for effecting national development (Federal Republic of Nigeria, 1999). Therefore, education shall continue to be highly rated in development plans because it is the most important instrument of change, either intellectually or socially, in any society. According to Vagale (1970), Teboho (2000) and Human Development Reports (2009), primary education is essential for the economic progress and social development of any country. There will not be accelerated economic growth and social change in a developing country like Nigeria without a modern and progressive educational system that is capable of developing to the full human potentials of the community and eradicating illiteracy and ignorance, providing the trained and skilled manpower required by the changing socio-economic system.

The provision and distribution of educational facilities are areas that need the input of physical planning professionals at the various levels of government in the country. In addition, planning for the location and distribution of public primary schools must be made on viable catchment population and a convenient travelling distance for primary school children. Education has a strong influence on people's earning capacity and productivity (Peterson, and Arnn, 2005). Also, it determines employment prospects and fundamental to people's ability to enjoy and appreciate all aspects of life. Therefore, no person should be deprived of accessibility to essential social services or basic needs because of lack of finance or its geographical location (Okafor, 2008).

Education is the key to development in any society and it is true that the educational institution in any given society reflects the standard of living and the attitudes towards life of that society (Saqib et al, 2010). Furthermore, it has been estimated that the level of illiteracy in Nigeria is as high as $68 \%$ (Wang, 1995) and such high illiteracy level is occasioned by lack of access to primary education by children of primary school age in the rural country side. This is probably, is as a result of inadequate access to public primary schools in the urban and rural areas that has necessitated the general urge by private organization and individuals for the establishments of private primary schools nowadays. Consequently, the need to correct this ugly trend by observing the present spatial inequality in accessing public primary schools cannot be over emphasized.

The need to review the existing distribution pattern of public primary schools across the local government areas in the country is essential, by means of appropriate planning efforts and initiative for the overall sustainable development in the sector. The need to plan for the spatial location and distribution of public services and facilities in any community is an essential task for the planners and public policy makers. Till date, there has been inadequate source of reliable information on the spatial distribution of primary schools and facilities in the study area. It is on this basis that the study aimed at advancing a spatial framework for the distribution of public primary schools in Munya local government area of Niger state Nigeria. This is with a view to identifying, mapping and determining the spatial equity and accessibility in the distribution of public primary schools in the Local Government Area (L.G.A.). This, no doubt, will constitute a reliable data base for determining the spatial location and distribution of public primary schools in the L.G.A. and any other parts of the country. Indeed, the document will lend itself to policy (framework) formulation for spatial distribution and allocation of scarce resources (financial, social and human) to public primary schools and other related physical development in the area. 
The study thus provoked a germane question: what significant role did population distribution play in the provision and distribution of public primary school in the study area? The question further prompted the following hypothesis:

There is no statistically significant relationship between population distribution and primary school provision in the study area.

\section{Materials and Methods}

Munya Local Government Area is one of the Gbayi speaking local government areas in Niger state, located to the North-Eastern part of the state with the headquarters at Sarki Pawa town. It is bordered in the north by Kaduna state, to the South by Paikoro Local Government Area and to the west by Shiroro Local Government Area respectively as indicated in figure 1.

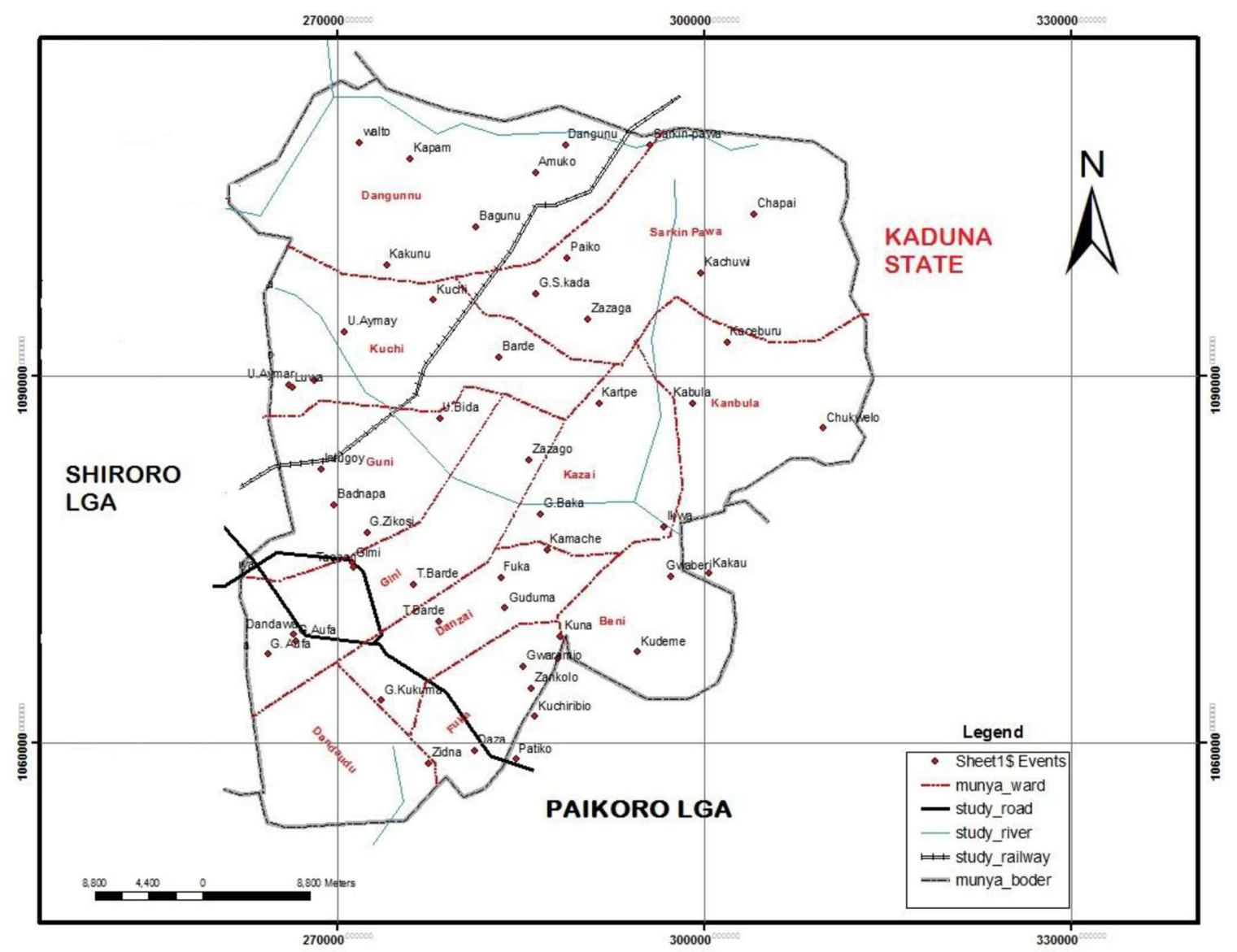

Figure 1: Ward Map of Munya Local Government Area

Source: Local Government and Chieftaincy Affairs, Minna

The local government area has eleven (11) administrative wards: Dangunu, Kazari, Guni, Beni, Sarki Pawa, Dandauda, Kuchi, Kabula, Daza, Fuka and Gini. Munya Local Government Area has an estimated population of 130,021 in 2014 (National Population Commission 2014), with an estimated number of primary schools of 20,673 and primary school enrolment of 12,489 with 109 public primary schools. The people of the area depend mostly on agriculture for sustenance.

The data used for this study were obtained mainly from both primary and secondary sources. List of available primary schools was obtained from the State Universal Basic Education Board, Niger 
State, verified from the Munya Local Education Authority (LEA) Office in Sarki Pawa. These schools were equally visited directly for on the spot survey on ward to ward basis, covering the eleven (11) wards in the local government area. This facilitated the picking of the coordinate numbers for geo-referencing and school-home distance measurement with the use of hand-held GPS. Other relevant information such as, student's enrolment and the number of teachers per school were obtained from the Local Education Authority (LEA).

To determine the degree of equity in Public schools' provision and distribution, an examination of the Location Quotient (LQ) values was done. This was conducted on ward basis and was don across the eleven (11) wards in Munya Local Government Area. Spearman's rank correlation co - efficient was further employed to explain the association between population ( $\mathrm{x}$ ) and primary schools provision (y) within the local government area. On the other hand, the P-median, a quantitative technique was used for determining the best location for public facilities, following Saad, (2011) and Arifin, (2011). P- median analysis was based on the maximum distance of 1-kilometre service radius required for pupils to access primary school in the study area.

\section{Results and Discussion}

Distribution of public primary school in Munya Local Government Area: The distribution of public primary school in Munya Local Government Area is uneven (Figure 2). A breakdown of the distribution of these primary schools as shown in Table 1 indicated that there are one hundred and nine (109) public primary schools with 11(10.1\%), 12(11.0\%), 20(18.3\%), 12(11.0\%), 13(11.9\%), 5(4.6\%), 5(4.6\%), 9(8.3), 7(6.4\%), 6(5.55) and 9(8.3\%) in Sarki Pawa, DanGunnu, Kuchi, Kanbula, Guni, Kanzai, Beni, Danzai, Fuka, Dandauda and Gini wards respectively.

Table 1: Distributional Equity of Public Primary School in Munya Local Government Area

\begin{tabular}{lccc}
\hline Wards & Ward Population & Schools & Percent-age \\
\hline Serkin Pawa & 20,649 & 11 & 10.1 \\
DanGunnu & 11,229 & 12 & 11.0 \\
Kuchi & 12,579 & 20 & 18.3 \\
Kanbula & 11,039 & 12 & 11.0 \\
Guni & 1,1498 & 13 & 11.9 \\
Kanzai & 9,088 & 5 & 4.6 \\
Beni & 9,057 & 5 & 4.6 \\
Danzai & 11,130 & 9 & 8.3 \\
Fuka & 12.427 & 7 & 6.4 \\
Dandaudu & 13,544 & 6 & 5.5 \\
Gini & 7,781 & 9 & 8.3 \\
\hline Total & 130,021 & 109 & 100 \\
\hline
\end{tabular}

Source: Authors Survey, 2014 


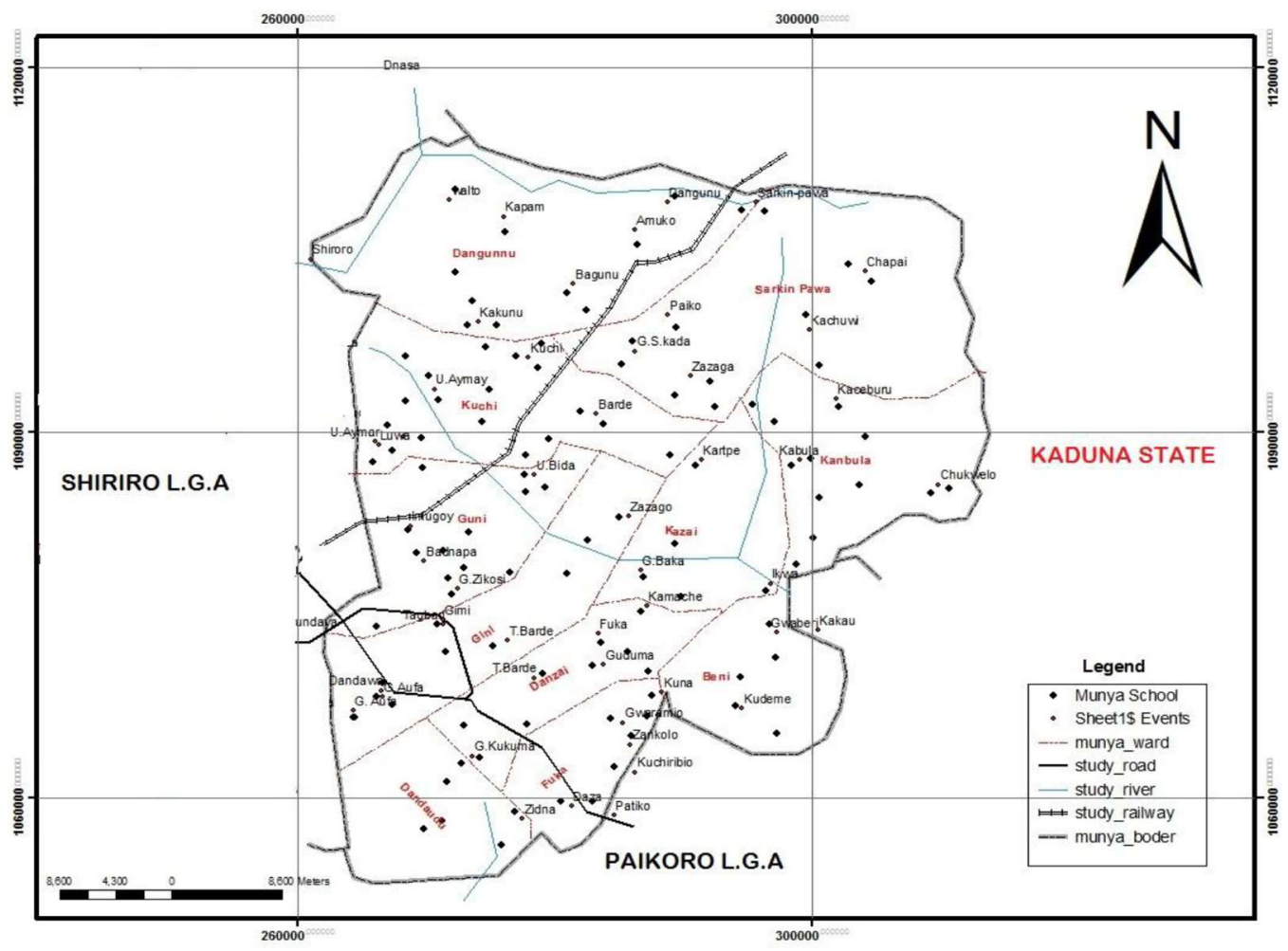

Figure 2: Public Primary Schools Distribution in Munya L.G.A Source: Local Government and Chieftaincy Affairs, Minna

Distributional Equity of Schools in the Local Government Area: The commonest measure of equity in the provision of public facilities is the equality among the various sub- units that constitute the study area (Ayeni et al 1986, Morenikeji 2006). In the case of public primary schools, an appropriate measure would be the number of schools-to-population ratios. There are 109 public primary schools in the local government area such that Sarki Pawa, DanGunnu, Kuchi, Kanbula, Guni, Kanzai, Beni, Danzai, Fuka, Dandaudu and Gini wards have public primary school to population ratio of 1:1877, 1: $942,1: 629,1: 918,1: 881,1: 1818,1: 1811,1: 1237,1: 1775,1: 2257$, and 1:765 respectively. This is shown in Table 2.

Table 2: Distributional Equity of Public Primary School in Munya Local Government Area

\begin{tabular}{lllll}
\hline Wards & Ward Population & Schools & Percent-age & Ratio \\
\hline Serkin Pawa & 20,649 & 11 & 10.1 & $1: 1,877$ \\
DanGunnu & 11,229 & 12 & 11.0 & $1: 942$ \\
Kuchi & 12,579 & 20 & 18.3 & $1: 629$ \\
Kanbula & 11,039 & 12 & 11.0 & $1: 918$ \\
Guni & 11,498 & 13 & 11.9 & $1: 881$ \\
Kanzai & 9,088 & 5 & 4.6 & $1: 1,818$ \\
Beni & 9,057 & 5 & 4.6 & $1: 1,811$ \\
Danzai & 11,130 & 9 & 8.3 & $1: 1,237$ \\
Fuka & 12.427 & 7 & 6.4 & $1: 1,775$ \\
Dandaudu & 13,544 & 6 & 5.5 & $1: 2,257$ \\
Gini & 7,781 & 9 & 8.3 & $1: 765$ \\
\hline Total & 130,021 & 109 & 100 & $1: 1,193$ \\
\hline
\end{tabular}

Source: Authors Survey, 2014 
Determination of the Degree of Equity in Public Primary Schools Provision: The Gini-coefficient estimated for the 109 public primary schools in the eleven (11) wards is 41.3 , with inequality value of 20.7 in the local government area. This value of Gini-coefficient shows a fair distribution of public primary schools in the local government area. This value is reasonable since it falls within the range of Gini-coefficient value of 0 - 100. From the values calculated in Table 3, it can, however, be seen that, six (6) wards Sarki Pawa (11),Kanzai (5), Beni (5), Danzai (9), Fuka (7) and Dandaudu (6) in the local government area are under served with public primary schools. On the other hand, Five (5) wards of DanGunnu, Kuchi, Kanbula, Guni and Gini are over serviced with 12, 20 , 12, 13 and 9 public primary schools respectively instead of 9.5, 10.5, 9.2, 9.6, and 6.5 schools each if population was the parameter considered in the distribution of schools among communities.

Determination of the Degree of Concentration of Schools in the L.G.A: An examination of the Location Quotient (LQ) values estimated for the wards in Munya Local Government Area as indicated in Table 4, shows that five (5) wards of Sarki Pawa, Kanzai, Beni, Fuka and Dandauda with $0.6,0.7,0.7,0.7$ and 0.5 Location Quotient (LQ) values respectively have less than fair share

Table 3: Gini - Co Efficient of Public Primary Schools in the 11 wards of Munya L.G.A

\begin{tabular}{ccccccc}
\hline Wards & Population(X) & Schools(Y) & Y\% & $\begin{array}{c}\text { Expected } \\
\text { YA }\end{array}$ & Y-YA & Pop \% \\
\hline Serkin Pawa & 20,649 & 11 & 10.1 & 17.3 & 6.3 & 15.9 \\
DanGunnu & 11,229 & 12 & 11.0 & 9.5 & 2.5 & 8.7 \\
Kuchi & 12,579 & 20 & 18.3 & 10.5 & 9.5 & 9.6 \\
Kanbula & 11,039 & 12 & 11.0 & 9.2 & 2.8 & 8.4 \\
Guni & 11,498 & 13 & 11.9 & 9.6 & 3.4 & 8.8 \\
Kanzai & 9,088 & 5 & 4.6 & 7.6 & 2.6 & 7.0 \\
Beni & 9,057 & 5 & 4.6 & 7.6 & 2.6 & 7.0 \\
Danzai & 11,130 & 9 & 8.3 & 9.3 & 0.3 & 8.6 \\
Fuka & 12.427 & 7 & 6.4 & 10.4 & 3.4 & 9.6 \\
Dandaudu & 13,544 & 6 & 5.5 & 11.4 & 5.4 & 10.4 \\
Gini & 7,781 & 9 & 8.3 & 6.5 & 2.5 & 6.0 \\
\hline Total & 130,021 & 109 & 100 & 109 & 41.3 & 100 \\
\hline
\end{tabular}

Source: Authors' Analysis, 2014.

of public primary schools. On the other hand, the five (5) wards of DanGunnu, Kuchi, Kanbula, Guni and Gini have more than fair share of public schools with 12.7, 1.9, 1.3, 1.4 and 1.4 Location Quotient (LQ) values respectively and only Danzai has a fair share with 1.0 Location Quotient.

Table 4: Location Quotient of Population and Public Primary Schools Provision

\begin{tabular}{cccclc}
\hline Wards & Schools & $\begin{array}{c}\text { Schools } \\
\text { Enrolment }\end{array}$ & Population & $\begin{array}{l}\text { Location Quotient/ } \\
\text { Ratios }\end{array}$ & LQ \\
\hline Serkin Pawa & 11 & 1,372 & 20,649 & $0.10092 / 0.15881$ & 0.6 \\
DanGunnu & 12 & 1,740 & 11,229 & $0.11009 / 0.00868$ & 12.7 \\
Kuchi & 20 & 1,999 & 12,579 & $0.18349 / 0.09675$ & 1.9 \\
Kanbula & 12 & 1,347 & 11,039 & $0.11009 / 0.08474$ & 1.3 \\
Guni & 13 & 1,555 & 11,498 & $0.11927 / 0.08806$ & 1.4 \\
Kanzai & 5 & 438 & 9,088 & $0.04587 / 0.06990$ & 0.7 \\
Beni & 5 & 726 & 9,057 & $0.04587 / 0.06966$ & 0.7 \\
Danzai & 9 & 987 & 11,130 & $0.08257 / 0.08560$ & 1.0 \\
Fuka & 7 & 737 & 12.427 & $0.06422 / 0.09558$ & 0.7 \\
\hline
\end{tabular}




\begin{tabular}{cccccc} 
Dandaudu & 6 & 814 & 13,544 & $0.05505 / 0.10417$ & 0.5 \\
Gini & 9 & 774 & 7,781 & $0.08257 / 0.05984$ & 1.4 \\
\hline Total & 109 & 12,489 & 130,021 & & \\
\hline
\end{tabular}

Source: Authors' Analysis, 2014

Relationship between Population Distribution and Primary Schools Provision: This section examines the relationship between population and primary schools' provision in the study area. The result of the spearman's rank correlation co-efficient as shown in Table 5 indicates a positive rank correlation co-efficient ( $r s$ ) of +0.34 . This index portrays a poor positive relationship between population distribution and primary schools' provision in the area. In testing for the statistical significance of the rank correlation co-efficient value, the student t-test was used.

Table 5: The Values of $t$ and $p$ of Population and Schools Provision in Munya L.G.A

\begin{tabular}{ccccc}
\hline L.G.A. & $\begin{array}{c}\text { Population } \\
\text { /Schools }\end{array}$ & $\mathrm{T}$ & P value & Remark \\
\hline Munya & Ho & 1.08 & 0.007 & Insignificant \\
\hline
\end{tabular}

(a) 0.005

\section{Source: Authors' Analysis, 2014}

At a confidence level of $0.05 \%$ and degree of freedom at 9 , the table value at $95 \%$, with $p=0.007$ $<0.05$, the association is significant. Therefore, the Null hypothesis (Ho) which states there is no statistically significant relationship between population distribution and public primary schools is rejected and the alternative hypothesis (Hi), that there is statistically significant relationship between population distribution and public primary schools in Munya Local Government Area of Niger state is accepted.

Result of analysis of the Underprivileged Settlements in Schools Provision in the Study Area: It was found that some of the settlements in the study area, are without public primary schools Figure 3. Therefore, primary school children in such settlements, cover more than the required maximum of one Kilometre distance, to access schools in places farther away from their homes. As shown in Table 6 , there are 41 and 7 settlements within and outside the buffer zones respectively.

Table 6: The Under Privileged Settlements in Munya L.G.A

\begin{tabular}{cccccc}
\hline L.G.A. & Population & Settlements & School & $\begin{array}{c}\text { No. of } \\
\text { Settlement }\end{array}$ & $\begin{array}{c}\text { No. of } \\
\text { Schools }\end{array}$ \\
\hline Munya & 130,021 & Within Buffer & Outside Buffer & & \\
\hline
\end{tabular}

Source: Authors' Analysis, 2014 


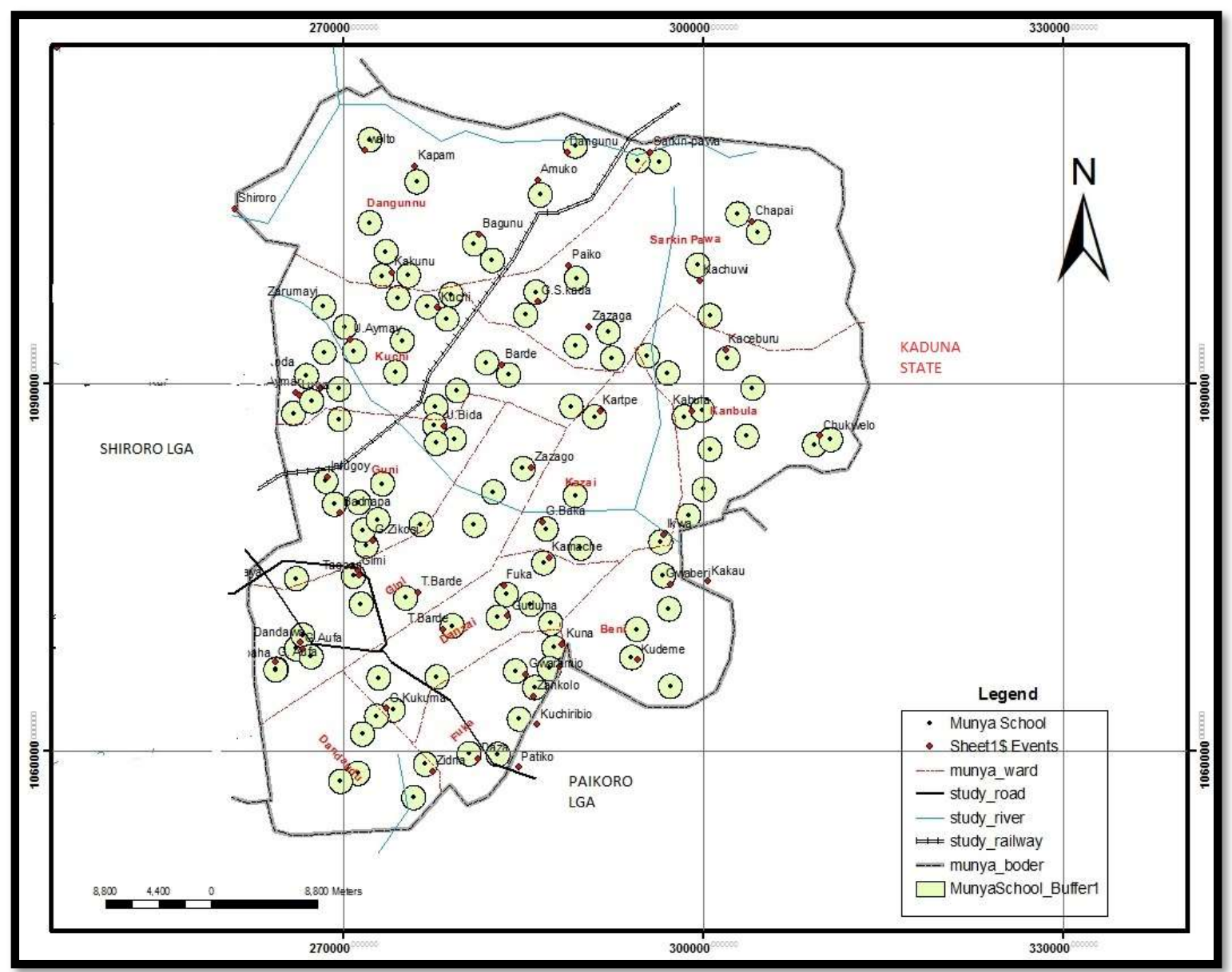

Figure 3: Schools buffering in Munya Local Government Area of Niger State Source: Authors' Analysis, 2014.

Median Analysis of Schools Provision and Distribution in the Study Area: The estimated P-median is a quantitative technique for determining the best location for public facilities (Saad, 2011, Arifin, 2011). The $\mathrm{P}$ - median analysis was based on the maximum distance of 1-kilometre service radius required for pupils to access schools in the study area. The results are presented in Table 7 and depicted in Figure 4.

Table 7: Iterations for Public Primary Schools Provision in Munya L.G.A

\section{Distribution and Distance}

\begin{tabular}{cccccc}
\hline $\begin{array}{c}\text { No. of Schools } \\
\text { Average } \\
\text { Distance }\end{array}$ & 109 & 42 & 37 & 36 & 38 \\
\hline
\end{tabular}

Source: Authors' Analysis, 2014.

Number of Settlements - 48, Number of Schools - 109

The analysis shows that 38 primary schools are optimally needed to sustain an average of $1.02 \mathrm{Km}$ for primary school pupils to get to schools as indicated in Table 7. 


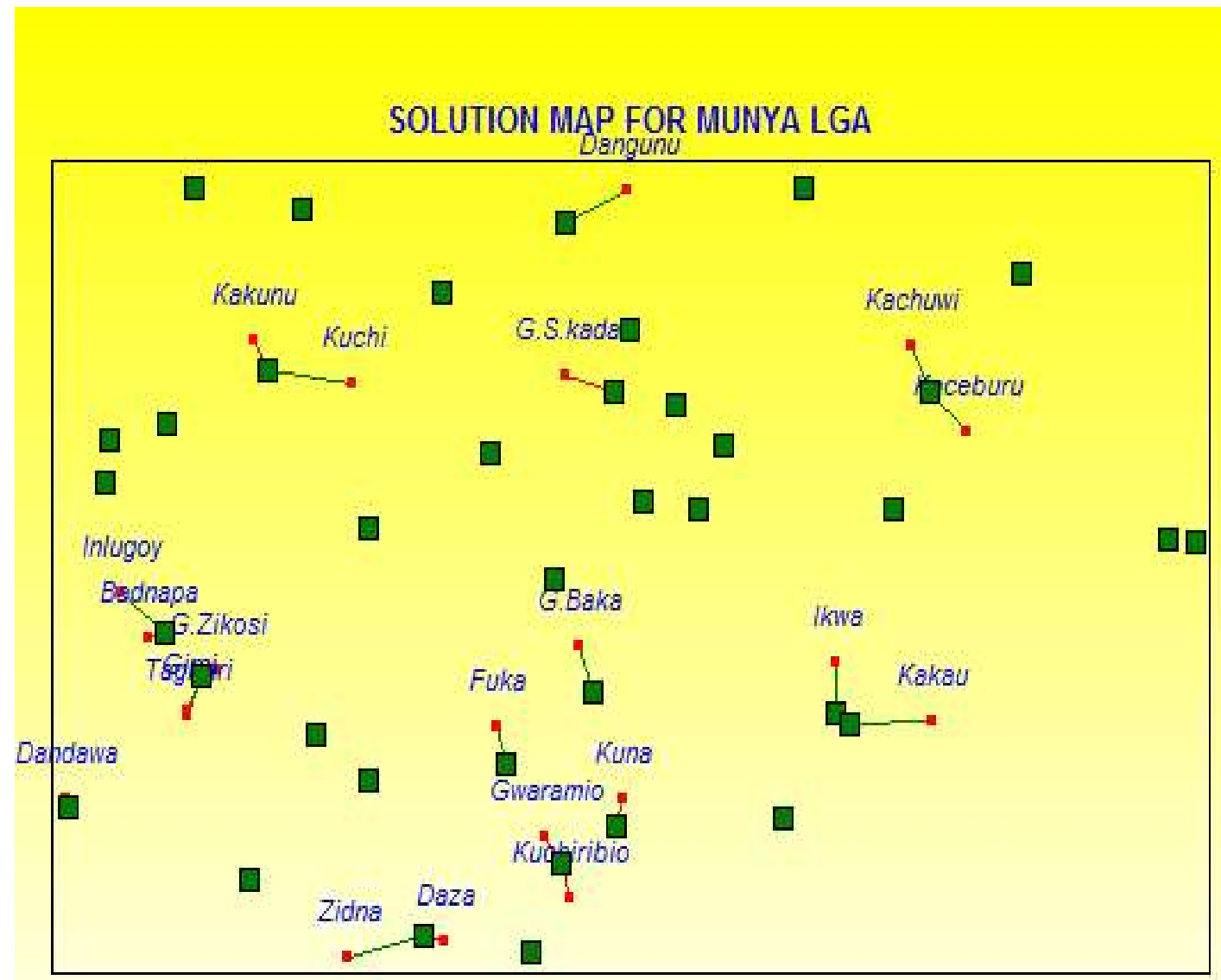

Figure 4: Solution Map of Munya L.G.A

Figure 4 indicates the geographical locations where if the schools are sighted will optimally serve the respective population around it within the optimum travel time and distance. This actual location can easily be identified for future siting of public primary school in the respective location with the use of GPS to establish the goe-references (co-ordinates).

\section{Conclusion}

The study analysed the location and distribution of public primary schools in Munya Local Government Area and identified the associated defects observed in most of the wards under considerations. Considering the role of education in the total eradication of illiteracy and key to growth and development of a people, the study underscore the need to be adequately guided in the location of public primary school in Munya local government of Niger State, Nigeria (the solution Map, Figure 4 will be helpful), to close access gaps, while the existing schools are renovated to provide for decent learning environment. This will sustain the likely future growth in school's enrolment in the study area

It is further noted that future public schools establishment be related to the needs of the population as the of the analysis will assist usin Location Quotient (LQ) and Gini co efficient on population and schools provision indicated that most wards are either under - served or over - served with schools. 


\section{References:}

Allen Consulting Group (2003): Funding Urban Infrastructure; Approaches Captured. A research document for the Property Council of Australia published as CAN 007061930 and posited on the Web www.allenConsult.com.au retrieved on March 8, 2014

Arifin, Shamsul M.D (2011): Location Allocation Problems using Genetic Algorithm and Simulated Annealing: A case study based on schools in Enschede; Master degree Thesis Faculty of Geo Information Science and Earth Observation of the University of Twente

Ayeni, B. and Ruston G. (1986): Distributional Equity and Efficiency in the Locational Analysis of Public Facilities: A case Study in Nigerian Geographical Journal Vol.29 pp 115- 135

Federal Republic of Nigeria (1999): National Population Commission Templates

Frischmann, B.M (2007): Infrastructure Commons in Economic Perspective. An article Published in First Monday Volume 12, No 6, 2006

Human Development Report (2009): United Nation Human Development Report of 2009: Overcoming Barriers in Human Mobility and Development p.68

Local Governments and Chieftaincy Affairs Commission (2014): Ministry of Local Government and Chieftaincy Affairs Directory, Old Secretariat Complex Minna Niger State

Mabogunje, A.L (1974): Cities and Social Order an Inaugural Lecture delivered at the University of Ibadan 2nd April, 1974 Ibadan University Press Ibadan

Morenikeji, O.O (2006): Research and Analytical Methods: For Social Scientists, Planners and Environmentalists Jos University Press Ltd 2006

National Population Commission (2006): Federal Republic of Nigeria, National Population Commission, Abuja

Peterson, T.O. and Arnn, R.B., (2005). Self-efficacy: The foundation of human performance. Performance Improvement Quarterly, 18(2), pp.5-18

Wang, H, (1995): Illiteracy in Nigeria. Does a Solution Exist? Eserver.org/courses/fall95/76

Okafor, S.I (2008): Health and Health care Facilities in Nigeria: The Problems of Equity and Equality in Environmental Planning and Health in Nigeria edited by Tunde Agbola et al pp.113 - 131

Saad, M. A. (2011): Distance and Coverage: An Assessment of Location Allocation Models for Fire Stations in Kuwait City Kuwait, a PhD Dissertation Kent State University.

Saqib, S et al (2010): Access and Equity in Basic Education in Asian Social Science Vol. 6 No. 8 retrieved on the $28^{\text {th }}$ May 2014.

Teboho, M (2000): Nigeria Education Sector Analysis: An Analytical Synthesis of Performance and Main Issues World Bank Document 2000

Vagale, L.R et al (1970): Manual of Space Standards for Urban Development, Ibadan Technical College, Ibadan. 